\title{
Kajian Pemberian Sari Kecambah Kacang Hijau (Vigna radiata L.) dan Sari Ubi Jalar Ungu (Ipomea batatas L.) Terhadap Mutu Nata De Coco
}

\author{
Elfi Anis Saati ${ }^{1}$, Rista Anggriani ${ }^{1}$, Anggie Audya Arwinda Rudiawaty ${ }^{1^{*}}$ \\ ${ }^{1}$ Program Studi Teknologi Pangan, Fakultas Pertanian Peternakan, Universitas Muhammadiyah \\ Malang, Malang, Indonesia. \\ *Corresponding author email: anggieaudya@gmail.com
}

\begin{abstract}
Nata de Coco is a fermented food product with coconut water as based ingredient which gives sugar as carbon source and $Z A$ as nitrogen sources. $Z A$ is known as a chemical ingredient and mug bean sprouts is natural ingredients which contain 20.5-21\% of nitrogen that can replace ZA. Nata de Coco is a product with low antioxidants, so it needs other ingredients to increase the antioxidant that is purple sweet potatoes known contain high antioxidant. Randomized block design (RBD) with 2 factors and 2 repetitions. The best treatment is H1J2 (7.5\% mung bean sprouts essence and 30\% purple sweet potatoes essence) with yield values $40.22 \%$, thickness $9.80 \mathrm{~mm}$, brightness (L) 48.15, redness (at) 3.75 , blueness $\left(b^{-}\right) 4.25$, antioxidant activity values $18.50 \%$, crude fiber content $2.49 \%$, taste 2.80 (less good), texture 4.48 (neutral), color 2.72 (less attractive), anthocyanin total 1,335 mg/L.
\end{abstract} Keywords: Mung Bean Sprouts, Nata de Coco, Purple Sweet Potatoes

\begin{abstract}
Abstrak. Nata de Coco merupakan produk pangan hasil fermentasi berbahan dasar air kelapa yang membutuhkan gula sebagai sumber karbon dan ZA sebagai sumber nitrogen. ZA dikenal sebagai bahan kimia dan kecambah kacang hijau mengandung 20,5-21\% nitrogen yang dapat digunakan untuk menggantikan ZA. Nata de Coco merupakan produk dengan kandungan antioksidan yang rendah, sehingga membutuhkan bahan lain untuk meningkatkan antioksidan yaitu ubi jalar ungu yang diketahui memiliki antioksidan yang tinggi. Rancangan Acak Kelompok (RAK) dengan 2 dan 2 ulangan. Perlakuan terbaik adalah H1J2 (sari tauge 7,5\% dan sari ubi ungu 30\%) dengan nilai rendemen 40,22\%, tebal 9,80 mm, kecerahan (L) 48,15, kemerahan (a +) 3, 75, kebiruan (b-) 4,25, nilai aktivitas antioksidan 18,50\%, kadar serat kasar 2,49\%, rasa 2,80 (kurang baik), tekstur 4,48 (netral), warna 2,72 (kurang baik) menarik), antosianin total $1.335 \mathrm{mg} / \mathrm{L}$.
\end{abstract}

Kata Kunci: Kecambah Kacang Hijau, Nata de Coco, Ubi Jalar Ungu.

\section{PENDAHULUAN}

Nata de Coco merupakan produk fermentasi yang membutuhkan Acetobacter xylinum untuk memproduksi selulosa yang merupakan bagian penyusun dari Nata de Coco itu sendiri (Sari, dkk., 2014). Acetobacter xylinum membutuhkan nutrisi agar dapat menghasilkan selulosa, berupa 
nitrogen. Pemenuhan zat nitrogen untuk pembuatan Nata de Coco didapat melalui penambahan ZA yang merupakan pupuk kimia buatan. Penggunaan ZA yang merupakan pupuk kimia dimungkinkan adanya cemaran dari logam berat atau cemaran lain hasil sintesis ZA. Selain itu, batas cemaran pada pupuk lebih tinggi dari bahan kimia pangan (Ikawati, 2015). Kacang hijau tergolong dalam jenis kacang tinggi protein. Kacang hijau diketahui memiliki kandungan protein sebesar 20-25\% (Martianingsih, 2016) dan mengandung nitrogen sebesar 20,5-21\% (Arifiani, 2015) yang dapat digunakan untuk mengganti ZA. Nata de Coco diketahui memiliki kandungan aktivitas antioksidan yang rendah sehingga perlu ditambahkan bahan yang dapat meningkatkan nilai aktivitas antioksidannya. Senyawa antioksidan dapat diperoleh dari ubi jalar ungu karena kandungan zat bioaktif yang merupakan zat pewarna alami yang disebut antosianin (Agung, 2012). Hasil penelitian Ina, dkk., (2019) tentang penambahan ekstrak ubi ungu pada soft candy menunjukkan bahwa semakin tinggi konsentrasi penambahan ekstrak ubi ungu semakin tinggi pula aktivitas antioksidan dan total antosianinnya. Antosianin dapat berfungsi sebagai antioksidan yang dapat mencegah terjadi penuaan, kanker, dan penyakit degeneratif (Saati, 2012 dan Salim, dkk., 2017). Kandungan antosianin pada ubi jalar ungu adalah $6,23 \mathrm{mg} / \mathrm{g}$ bahan kering (Ji, 2015). Penambahan ini dapat meningkatkan nilai aktivitas antioksidan pada produk.

Penambahan sari kecambah kacang hijau sebagai pengganti ZA dan sari ubi jalar ungu pada pembuatan Nata de Coco untuk meningkatkan kualitas mutu pada produk Nata de Coco. Penambahan sari ubi jalar ungu juga dapat memberikan warna ungu pada produk sehingga produk dapat memiliki warna yang baru dan berbeda dari produk pasaran.

\section{METODE PENELITIAN}

\section{Bahan}

Bahan yang dibutuhkan untuk membuat Nata de Coco adalah air kelapa yang diperoleh dari Pasar Mojosari, gula, ZA yang dibeli dari daerah Cilegon, kecambah kacang hijau diperoleh dari Pasar Mojosari, ubi jalar ungu diperoleh dari Pasar Mojosari, starter Acetobacter xylinum yang dibeli dari daerah Serang. Sedangkan bahan untuk analisa berupa aquades, larutan buffer, DPPH (2,2diphenyl-1-picrylhydrazyl), $\mathrm{KCl}$ 0,025 M, Na-asetat 0,4 M, metanol p.a, dan $\mathrm{HCl}$ $37 \%$.

Alat

Alat yang digunakan untuk membuat Nata de Coco adalah pisau, talenan, parutan, sendok, kompor, panci, timbangan, blender, kain saring, gelas ukur, baskom, saringan, loyang ukuran $16 \times 21 \mathrm{~cm}$, koran, karet, rak kayu. Sedangkan alat untuk analisa adalah alat-alat gelas, rak tabung, vortex, kertas saring, neraca 
analitik, spektrofotometer thermo spectronic (GENESYS 20), colour reader (CR10 'Konica Minolta'), centrifuge (PLC Series), dan alat pendukung lainnya.

\section{Rancangan Penelitian}

Penelitian dilakukan secara Rancangan Acak Kelompok Faktorial yang terdiri dari dua faktor. Faktor I adalah konsentrasi sari kecambah kacang hijau dengan 3 level yakni $0 \%, 7,5 \%, 15 \%$, sedangkan faktor II adalah konsentrasi sari ubi jalar ungu dengan 3 level yakni $0 \%, 15 \%$, dan 30\%. Pengulangan pada penelitian ini dilakukan sebanyak dua kali.

\section{Pembuatan Sari Kecambah Kacang Hijau}

Pembuatan sari kecambah kacang hijau mengacu pada Indrawati, dkk., (2017), yang dilakukan dengan cara sederhana yakni kacang hijau dihaluskan dengan penambahan air kelapa dengan perbandingan 1:3. Setelah itu sari kecambah kacang hijau disimpan di wadah tertutup.

\section{Pembuatan Sari Ubi Jalar Ungu}

Pembuatan sari ubi jalar ungu Nazhipah, dkk. (2019), dengan cara sederhana yakni ubi jalar ungu dihaluskan dengan diparut lalu diperas dengan kain saring untuk mendapat sari ubi jalar ungu. Setelah didapat sari ubi jalar ungu disimpan di wadah tertutup.

\section{Pembuatan Nata de Coco}

Proses pembuatan Nata de Coco adalah air kelapa sebanyak $500 \mathrm{~mL}$ yang telah disimpan selama 4 hari (Layuk, dkk., 2012 dalam Putri, dkk., 2021) dipanaskan hingga mendidih lalu ditambahkan gula pasir 2,5\% (b/v) dan sari kecambah kacang hijau (konsentrasi 0\%, 7,5\%, dan 15\%) (v/v), untuk sari kecambah kacang hijau 0\% akan diganti dengan ZA sebanyak 0,5\% (b/v), diaduk dengan tetap dipanaskan. Selanjutnya ditambahkan sari ubi jalar ungu (konsentrasi 0\%, 15\%, dan 30\%) (v/v) tetap didihkan sebentar dengan api kecil (Nazhipah, dkk., 2018). Larutan dituang ke dalam loyang plastik ukuran 16 x 21 $\mathrm{cm}$ dan ditutupi dengan koran. Setelah itu dilakukan pendinginan hingga media bersuhu sekitar $30^{\circ} \mathrm{C}$. Air kelapa yang telah dingin ditambahkan $10 \%(\mathrm{v} / \mathrm{v}) \mathrm{kultur}$ Acetobacter xylinum (Pratiwi, dkk., 2012). Loyang plastik ditutup lagi dengan kertas koran lalu difermentasi selama 7 hari pada suhu kamar. Setelah 7 hari nata dipanen dan dilakukan pencucian lalu dilakukan perendaman selama 3 × 24 jam dan dilakukan penggantian air tiap harinya. Setelah perendaman selama 3 hari atau sampai aroma asam pada produk hilang, dilakukan pemotongan dengan ukuran berkisar $1 \times 1 \mathrm{~cm}$ lalu dilakukan perebusan dengan suhu $110-120^{\circ} \mathrm{C}$ selama 10-20 menit.

\section{Parameter Penelitian}

Pengamatan yang dianalisa pada penelitian ini meliputi analisis rendemen (Margi, dkk., 2017), ketebalan (Rosel, dkk., 2018), intensitas warna (de Man, 1999 dalam Minerva, 2013), kadar serat kasar (\%) (Rosel, dkk., 2018), aktivitas 
antioksidan (Su, 2004 dalam Septiana, dkk., 2013), organoleptik (Rahayu, 2001 dalam Suryono, dkk., 2018) meliputi, rasa, tekstur, dan warna guna menguji tingkat penerimaan produk oleh panelis, dan total antosianin (Putri, dkk., 2015).

\section{Analisa Data}

Analisis pengolahan data hasil pengamatan penelitian dilakukan menggunakan analisis ragam atau disebut analysis of variance (ANOVA) pada taraf $5 \%$ dan $1 \%$. Dan jika didapatkan hasil yang berbeda nyata akan dilanjutkan uji DMRT. Sedangkan untuk mengetahui hasil perlakuan terbaik dilakukan uji De Garmo.

\section{HASIL DAN PEMBAHASAN}

\section{Analisa Bahan Baku}

Analisa bahan baku ini dilakukan pada bahan baku segar. Umur panen pada kecambah kacang hijau adalah 5 hari. Umur panen ubi jalar ungu adalah 4 bulan. Analisa bahan baku ini meliputi kadar serta kasar (\%), aktivitas antioksidan (\%), dan total antosianin $(\mathrm{mg} / \mathrm{L})$. Hasil analisa bahan baku dapat dilihat pada tabel berikut:

Tabel 1. Hasil Analisa Bahan Baku Kecambah Kacang Hijau

\begin{tabular}{|c|c|c|c|c|}
\hline \multirow{2}{*}{ Karakteristik } & \multicolumn{2}{|c|}{ Kecambah Kacang Hijau } & \multicolumn{2}{|c|}{ Ubi Jalar Ungu } \\
\hline & Hasil Analisa & Literatur & Hasil Analisa & Literatur \\
\hline $\begin{array}{l}\text { Kadar Serat } \\
\text { Kasar (\%) }\end{array}$ & 0,98 & $\begin{array}{l}\text { 1,80 (USDA, } \\
2018)\end{array}$ & 0,37 & $\begin{array}{l}\text { 0,30 Hasbullah, } \\
2001 \text { dalam } \\
\text { Hassan, 2014) }\end{array}$ \\
\hline $\begin{array}{l}\text { Aktivitas } \\
\text { Antioksidan (\%) }\end{array}$ & 67,42 & $\begin{array}{c}\text { 72,02 (Wulaisfan, } \\
\text { dkk., 2016) }\end{array}$ & 75,66 & $\begin{array}{c}\text { 59,25 Husna, dkk., } \\
\text { 2013) }\end{array}$ \\
\hline $\begin{array}{l}\text { Total Antosianin } \\
(\mathrm{mg} / \mathrm{L})\end{array}$ & & - & 57,78 & $\begin{array}{c}\text { 61,85 Husna, dkk., } \\
\text { 2013) }\end{array}$ \\
\hline
\end{tabular}

Hasil analisis bahan baku berupa uji kadar serat kasar (\%), aktivitas antioksidan (\%), dan total antosianin ( $\mathrm{mg} / \mathrm{L})$ menghasilkan nilai yang perbedaannya tidak terlalu jauh. Baik dari bahan baku kecambah kacang hijau atau ubi jalar ungu. Perbedaan pada aktivitas antioksidan kecambah kacang hijau dapat disebabkan adanya perbedaan umur bahan baku ketika pengujian berlangsung. Aktivitas antioksidan pada kecambah kacang hijau berasal dari kandungan vitamin $\mathrm{C}$ sebesar 13,2 $\mathrm{mg}$, vitamin $\mathrm{E}$ sebesar 0,10 $\mathrm{mg}$ dan betakaroten sebesar $6 \mu \mathrm{g}$ (USDA, 2018).

Sedangkan untuk pengujian ubi jalar ungu memiliki nilai aktivitas antioksidan dan total antosianin dipengaruhi oleh tinggi rendahnya kandungan antosianin yang ada pada ubi jalar ungu. Semakin gelap warna ungu pada umbinya, maka dapat disimpulkan bahwa kandungan antioksidan dan total antosianin pada ubi jalar ungu tersebut akan semakin tinggi. Husna, dkk., (2013), menyatakan bahwa kadar antosianin pada ubi jalar ungu pekat lebih tinggi 17 
kali lipat dari pada kandungan antosianin pada ubi jalar muda. Sedangkan ada perbedaan hasil pengujian yang lain dapat dipengaruhi oleh perbedaan bagian bahan yang diujikan dan dapat pula karena adanya perbedaan varietas sampel.

\section{Rendemen}

Hasil analisis ragam penambahan sari kecambah kacang hijau dan sari ubi jalar ungu menunjukkan bahwa tidak terjadi interaksi terhadap rendemen. Penambahan sari kecambah kacang hijau dan sari ubi jalar ungu tidak berpengaruh secara nyata terhadap rendemen.
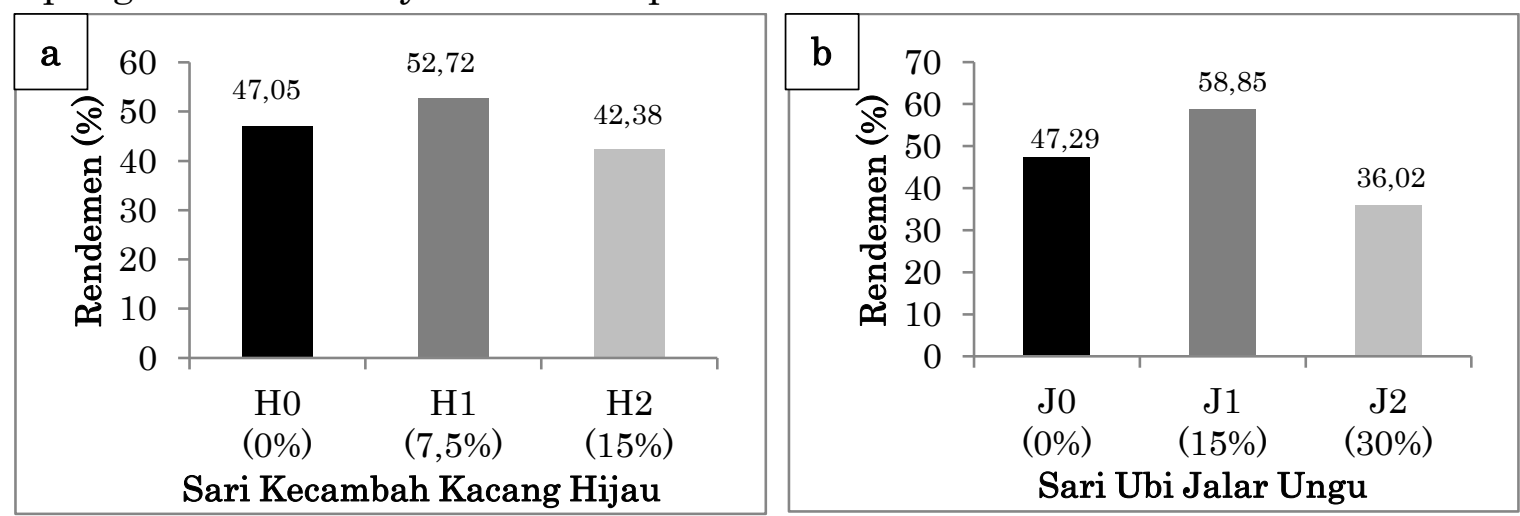

Gambar 1. Histogram Rendemen a. Pengaruh Pemberian Sari Kecambah Kacang Hijau dan b. Pengaruh Pemberian Sari Ubi Jalar Ungu

Kacang hijau diketahui memiliki kandungan nitrogen sebesar 20,5-21\% (Arifiani, 2015). Nitrogen ini diperlukan untuk pembentukan asam nukleat yang berguna sebagai penyimpan informasi genetika dan menurunkannya dalam bentuk DNA. Ketersediaan nitrogen mengakibatkan peningkatan jumlah dari Acetobacter xylinum. Dengan meningkatnya jumlah dari Acetobacter xylinum dapat menyebabkan peningkatan jumlah selulosa yang dapat dihasilkan (Melina, 2016). Menurut Ningsih, dkk. (2021), yang menyimpulkan bahwa penggunaan ekstrak kecambah nyata mempengaruhi ketebalan Nata. Diketahui pula berdasarkan penelitian Melina (2016), mendapatkan hasi tertinggi pada konsentrasi $10 \%$.

Menurut Lempang (2007) dalam Safitri, dkk. (2017), yakni dengan tingginya total nutrient yang diimbuhkan pada media fermentasi akan berakibat pada peningkatan rendemen hingga batas optimum. Selanjutnya jika sediaan nutrient pada media yang total inokulumnya tinggi, maka nutrien bisa menjadi toksik untuk mikroba. Akibat dari hal itu nata tidak terbentuk secara maksimal.

\section{Ketebalan}

Hasil analisis ragam penambahan sari kecambah kacang hijau dan sari ubi jalar ungu menunjukkan bahwa tidak terjadi interaksi terhadap ketebalan. Penambahan sari kecambah kacang hijau dan sari ubi jalar ungu berpengaruh nyata terhadap ketebalan. Ketebalan Nata de Coco (Tabel 3) dipengaruhi oleh 
aktivitas Acetobacter xylinum yang membentuk jalinan selulosa dengan cara mengubah glukosa yang terkandung dalam media menjadi selulosa. Putranto (2017), mendapatkan hasil penelitian berupa semakin tinggi kadar ekstrak tauge yang ditambahkan akan semakin tinggi pula ketebalan nata de coco yang dihasilkan. Menurut Rosel, dkk., (2018), standar SNI dari ketebalan nata de coco ialah 1-1,5 cm. Tabel 2 menunjukkan bahwa sebagian perlakuan termasuk pada standar SNI yang ada. Dari hasil penelitian Melina (2016), diketahui bahwa ketebalan tertinggi diperoleh oleh penambahan sari kecambah kacang hijau konsentrasi 10\%, sedangkan untuk penamban sari ubi jalar ungu sebanyak $100 \mathrm{~g}$ dalam 2 L akan menghasilkan nilai ketebalan berkisar 1,6 cm (Nazhipah, dkk., 2018).

Tabel 2. Nilai Ketebalan Nata de Coco

\begin{tabular}{lc}
\hline \multicolumn{1}{c}{ Perlakuan } & Ketebalan (mm) \\
\hline H0 (Sari Kecambah Kacang Hijau 0\%) & $8,23^{\mathrm{a}}$ \\
H1 (Sari Kecambah Kacang Hijau 7.5\%) & $10,08^{\mathrm{b}}$ \\
H2 (Sari Kecambah Kacang Hijau 15\%) & $10,05^{\mathrm{b}}$ \\
\hline J0 (Sari Ubi Jalar Ungu 0\%) & $8,95^{\mathrm{a}}$ \\
J1 (Sari Ubi Jalar Ungu 15\%) & $10,70^{\mathrm{b}}$ \\
J2 (Sari Ubi Jalar Ungu 30\%) & $8,71^{\mathrm{a}}$ \\
\hline Komersil & 9,90
\end{tabular}

Keterangan: Angka-angka yang diikuti oleh huruf kecil yang berbeda menunjukkan berbeda nyata berdasarkan uji DMRT ( $\alpha=5 \%)$

\section{Kadar Serat Kasar}

Hasil analisis ragam penambahan sari kecambah kacang hijau dan sari ubi jalar ungu menunjukkan bahwa tidak terjadi interaksi terhadap kadar serat kasar (\%). Penambahan sari kecambah kacang hijau dan sari ubi jalar ungu berpengaruh nyata terhadap kadar serat kasar (\%).

Tabel 3. Nilai Kadar Serat Kasar Nata de Coco

\begin{tabular}{lc}
\hline \multicolumn{1}{c}{ Perlakuan } & Kadar Serat (\%) \\
\hline H0 (Sari Kecambah Kacang Hijau 0\%) & $2,05^{\mathrm{a}}$ \\
H1 (Sari Kecambah Kacang Hijau 7,5\%) & $2,18^{\mathrm{ab}}$ \\
H2 (Sari Kecambah Kacang Hijau 15\%) & $2,28^{\mathrm{b}}$ \\
\hline J0 (Sari Ubi Jalar Ungu 0\%) & $1,79^{\mathrm{a}}$ \\
J1 (Sari Ubi Jalar Ungu 15\%) & $2,29^{\mathrm{b}}$ \\
J2 (Sari Ubi Jalar Ungu 30\%) & $2,43^{\mathrm{b}}$ \\
\hline Komersil & 1,23
\end{tabular}

Keterangan: Angka-angka yang diikuti oleh huruf kecil yang berbeda menunjukkan berbeda nyata berdasarkan uji DMRT ( $\alpha=5 \%)$

Hasil analisis kadar serat kasar (\%) menghasilkan kesimpulan bahwa semua perlakuan baik penambahan sari kecambah kacang hijau dan sari ubi jalar 
ungu sama-sama tergolong dalam SNI dari Nata de Coco dalam kemasan. SNI No. 01-4317-1996 yaitu kadar serat maksimum 4,5\% (BSN, 1996). Penelitian oleh Nazhipah, dkk., (2018), menghasilkan data kadar serat berkisar 2,9\% pada pembahan sari ubi jalar ungu, sedangkan penelitian Safitri, dkk., (2017) menghasilkan data kadar serat berkisar $0,24 \%$ pada penambahan sari kecambah kacang hijau sebagai sumber nitrogen. Berdasarkan rerata serat yang ada dengan nilai rerata $2 \%$ ini belum bisa dikatakan pangan sumber serat ataupun tinggi serat karena berdasarkan peraturan Kepala Badan Pengawas Obat dan Makanan (BPOM) Republik Indonesia Nomor HK.03.1.23.11.11.09909 tahun 2011, menerangkan bahwa pangan sumber serat harus mengandung serat setidaknya 3 g/ $100 \mathrm{~g}$ pangan, sedangkan pangan tinggi serat harus memiliki kadar serat setidaknya $6 \mathrm{~g} / 100 \mathrm{~g}$ bahan pangan (BPOM RI, 2011).

Putranto (2017) menyatakan bahwa peningkatan jumlah selulosa yang relatif cepat diduga karena akibat konsentrasi sel yang terus berkembang di daerah permukaan yang langsung berkontak dengan udara di dalam wadah fermentasi. Suplai oksigen di permukaan merangsang peningkatan massa sel dan enzim pembentuk selulosa, yang berakibat pada peningkatan selulosa yang menyebabkan peningkatan kadar serat pada nata.

\section{Tingkat Kecerahan (L) Nata de Coco}

Hasil analisis ragam penambahan sari kecambah kacang hijau dan sari ubi jalar ungu menunjukkan bahwa tidak terjadi interaksi terhadap tingkat kecerahan (L). Penambahan sari kecambah kacang hijau tidak berpengaruh nyata dan sari ubi jalar ungu berpengaruh nyata terhadap tingkat kecerahan $(\mathrm{L})$.

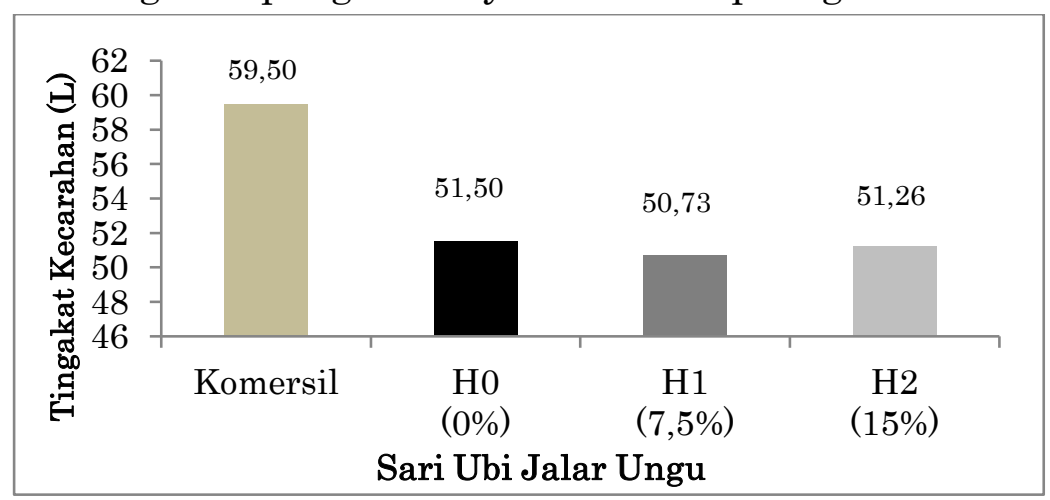

Gambar 2. Tingkat Kecerahan (L) akibat Pemberian Sari Kecambah Kacang Hijau

Kecerahan tertinggi (L) (Gambar 2) terdapat pada perlakuan 0\% dengan nilai 51,50. Hal ini karena tidak adanya penambahan sari kecambah kacang hijau yang menyebabkan warna yang dihasilkan putih keruh saja. Sedangkan penambahan sari kecambah kacang hijau menghasilkan warna krem kuning kehijauan. Hal ini sejalan dengan pernyataan Putranto, dkk. (2017), yang menyatakan bahwa ekstrak tauge berwarna putih krem. Nata yang dihasilkan dengan penambahan ekstrak tauge adalah putih hingga jernih agak krem. 
Kejernihan dan transparansi dari nata dipengaruhi oleh media fermentasi dan ketebalan nata itu sendiri.

Tingkat kecerahan (L) (Tabel 4) memiliki nilai yang semakin menurun dengan penambahan konsentrasi sari ubi jalar ungu. Hal ini sejalan dengan penelitian dari Ina, dkk (2019) yang menyatakan bahwa semakin tinggi penambahan ubi jalar ungu pada soft candy akan memberikan warna yang lebih kuat. Warna ungu dari ubi jalar ungu merupakan pigmen ungu antosianin yang terkandung pada ubi jalar ungu dan menyebar dari kulit hingga daging umbinya (Pokorny, dkk., 2001 dalam Fendri, dkk, 2018). Produk komersial memiliki tingkat kecerahan paling tinggi dikarenakan oleh selama masa pembuatan tidak terjadi penambahan zat yang dapat memberikan warna pada produk Nata de Coco komersial.

Tabel 4. Tingkat Kecerahan (L) akibat Pemberian Sari Ubi Jalar Ungu

\begin{tabular}{lc}
\hline \multicolumn{1}{c}{ Sari Ubi Jalar Ungu } & L \\
\hline J0 (Sari Ubi Jalar Ungu 0\%) & $58,26^{\mathrm{b}}$ \\
J1 (Sari Ubi Jalar Ungu 15\%) & $47,90^{\mathrm{a}}$ \\
J2 (Sari Ubi Jalar Ungu 30\%) & $47,33^{\mathrm{a}}$ \\
\hline Komersil & 59,50
\end{tabular}

Keterangan: Angka-angka yang diikuti oleh huruf kecil yang berbeda menunjukkan berbeda nyata berdasarkan uji DMRT ( $\alpha=5 \%)$

\section{Tingkat Kemerahan (a+) dan Tingkat Kebiruan (b-)}

Berdasarkan hasil analisis ragam sari kecambah kacang hijau dan sari ubi jalar ungu tidak terjadi interaksi pada tingkat kemerahan (a+) dan kebiruan (b-). Penambahan sari kecambah kacang hijau tidak berpengaruh nyata terhadap tingkat kemerahan $(\mathrm{a}+)$ dan kebiruan $\left(\mathrm{b}^{-}\right)$, sari ubi jalar berpengaruh nyata terhadap tingkat kemerahan $(\mathrm{a}+)$ dan ungu tidak berpengaruh nyata pada tingkat kebiruan (b-).

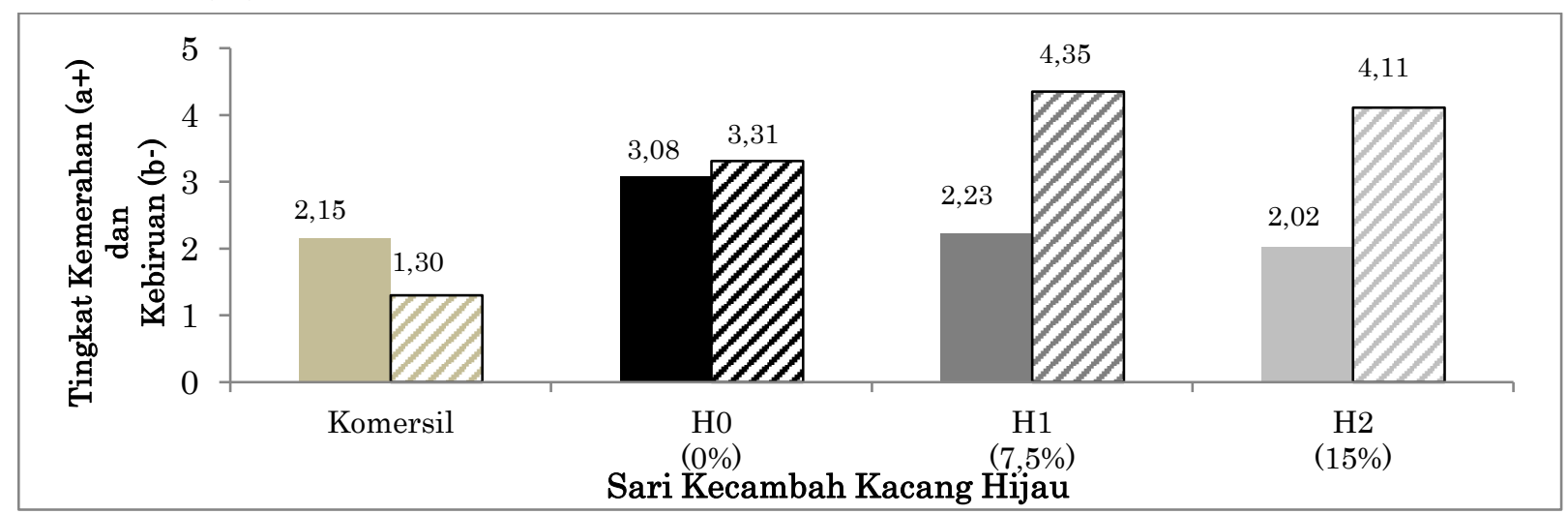

Gambar 3. Tingkat Kemerahan a+ dan Tingkat Kebiruan b- (striped bar) akibat Pemberian Sari Kecambah Kacang Hijau.

Hasil analisis terhadap penambahan sari kecambah kacang hijau pada tingkat kemerahan (a+) dan tingkat kebiruan (b-) (Gambar 3) menghasilkan nilai 
tertinggi pada perlakuan 0\% pada tingkat kemerahan (a+) dan 7,5\% pada tingkat kebiruan (b-) dengan nilai yang berurutan 3,08 dan 4,35. Selain itu warna juga dapat dipengaruhi oleh tingkat ketebalan produk, semakin gelap produk maka warna yang didapat semakin gelap (Putriana, dkk., 2013). Penelititan dari Nazhipah, dkk., (2018) menghasilkan nata yang berwarna putih ke unguan dengan penambahan ekstrak kulit ubi ungu sebanyak $100 \mathrm{~g}$ dalam $2 \mathrm{~L}$ media.

Tingkat kemerahan (a+) (Tabel 5) pada produk disebabkan oleh pigmen peonidin yang memberikan warna merah pada produk. Peonidin merupakan pigmen antosianin yang dominan pada ubi jalar ungu (Mahmudatussa'adah, dkk., 2014). Tetapi perlakuan $0 \%$ memiliki nilai $-1,33$ yang berarti kecenderungan warna yang dihasilkan adalah warna kuning. Hal ini karena produk tidak diberi perlakuan penambahan sari ubi jalar ungu sehingga warna yang dihasilkan hanya putih keruh agak krem.

Hasil tingkat kebiruan (b-) (Gambar 4) dipengaruhi oleh $\mathrm{pH}$ produk. $\mathrm{pH}$ produk saat fermentasi adalah 4-5 sehingga memiliki warna ungu, dan setelah fermentasi berakhir produk memiliki $\mathrm{pH}$ yang meningkat yakni berkisar 7 yang menyebabkan warna pada produk menjadi ungu kebiruan. Hal ini dikarenakan antosianin pada ubi jalar ungu dapat merubah warna sesuai dengan pHnya. Pada pH 1-3 akan berwarna merah, pada $\mathrm{pH}$ 4-6 akan berwarna ungu, pada $\mathrm{pH} 7$ akan berwarna biru, pada $\mathrm{pH}$ 8-9 akan berwarna hijau, pada $\mathrm{pH}$ 10-14 akan berwarna kuning (Mahmudatussa'adah, dkk., 2014).

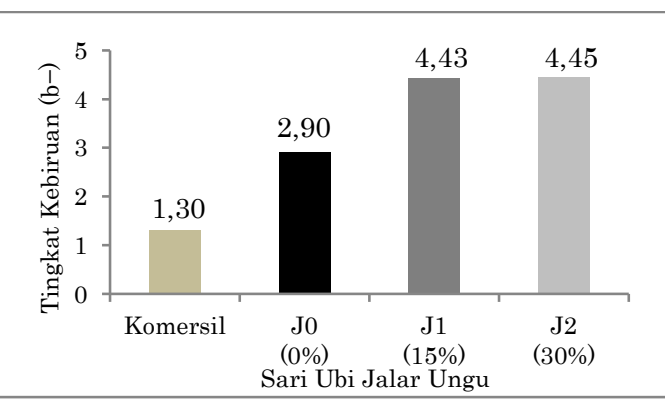

Gambar 4. Tingkat Kebiruan (b-) akibat Pemberian Sari Ubi Jalar Ungu

\section{Aktivitas Antioksidan (\%)}

Tabel 5. Tingkat Kemerahan (a+) akibat Pemberian Sari Ubi Jalar Ungu

\begin{tabular}{lc}
\hline \multicolumn{1}{c}{ Ubi Jalar Ungu } & $\mathrm{a}^{+}$ \\
\hline J0 (Sari Ubi Jalar Ungu 0\%) & $-1,33^{\mathrm{a}}$ \\
J1 (Sari Ubi Jalar Ungu 15\%) & $4,65^{\mathrm{b}}$ \\
J2 (Sari Ubi Jalar Ungu 30\%) & $4,01^{\mathrm{b}}$ \\
\hline Komersil & 2,15 \\
\hline
\end{tabular}

Keterangan: Angka-angka yang diikuti oleh huruf kecil yang berbeda menunjukkan berbeda nyata berdasarkan uji DMRT ( $\alpha=5 \%$ )

Hasil analisis ragam penambahan sari kecambah kacang hijau dan sari ubi jalar ungu menunjukkan bahwa tidak terjadi interaksi terhadap aktivitas antioksidan (\%). Penambahan sari kecambah kacang hijau dan sari ubi jalar ungu tidak berpengaruh secara nyata terhadap aktivitas antioksidan (\%). 

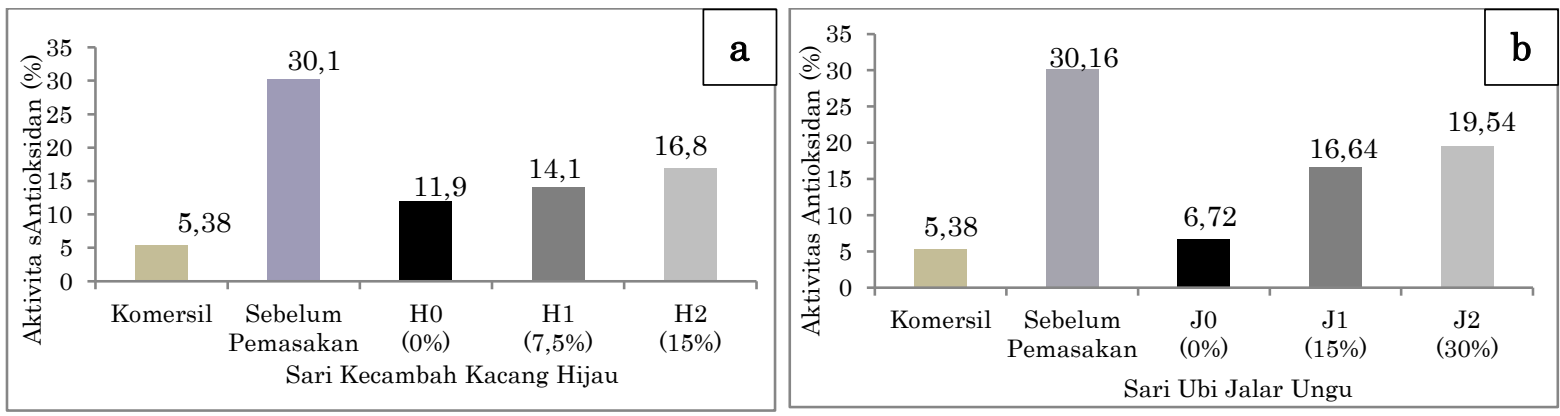

Gambar 5. Aktivitas Antioksidan akibat a. Pemberian Sari Kecambah Kacang Hijau dan b. Pemberian Sari Ubi Jalar Ungu

Semakin tinggi jumlah sari kecambah kacang hijau yang ditambahkan maka semakin tinggi pula aktivitas antioksidannya. Kecambah kacang hijau per $100 \mathrm{~g}$ memiliki kandungan vitamin C sebesar 13,2 mg, vitamin E sebesar 0,10 mg dan beta karoten sebesar 6 jg (USDA, 2018). Wulaisfan, dkk. (2016), yang mengatakan bahwa ekstrak kecambah biji kacang hijau memiliki kemampuan antioksidan dan memiliki \% pengikatan DPPH sebesar 72,02\% dengan konsentrasi 10 ppm dan memiliki IC $_{50}$ sebesar 0,998.

Aktivitas antioksidan akibat pemberian sari ubi jalar ungu (Gambar 5b) tertinggi terdapat pada perlakuan J2 (sari ubi jalar ungu 30\%). Hasil analisis aktivitas antioksidan akibat pemberian sari ubi jalar ungu memiliki nilai yang rendah, hal ini disebabkan karena adanya proses pemanasan berulang dengan suhu yang tinggi. Antosianin yang merupakan senyawa antioksidan yang terdapat pada ubi jalar ungu memiliki kestabilan pemanasan pada suhu $50^{\circ} \mathrm{C}$ dan akan mulai terdegradasi pada diatas suhu $75^{\circ} \mathrm{C}$ (Harbone dalam Laksmiani, dkk., 2015). Ina, dkk., (2019) dan Nazhipah, dkk., (2018) sama sama menyatakan semakin tinggi penambahan ekstrak ubi jalar ungu akan meningkatkan nilai aktivitas antioksidan pada produk.

\section{Uji Organoleptik Rasa}

Berdasarkan hasil analisis ragam sari kecambah kacang hijau dan sari ubi jalar ungu tidak terjadi interaksi. Penambahan sari kecambah kacang hijau tidak berpengaruh nyata terhadap organoleptik rasa, sari ubi jalar ungu berpengaruh nyata terhadap organoleptik rasa.

Nilai dari semua perlakuan yang berkisar skor 2 yang berarti rasa dari Nata de Coco yang dihasilkan tidak enak. Hal ini karena saat dilakukan pengujian organoleptik Nata de Coco tidak disajikan dengan larutan gula, sehingga nata yang dirasakan memiliki rasa yang hambar dan panelis tidak menyukainya sehingga memilih memberikan nilai skor yang rendah. Putriana (2013), menyatakan bahwa rasa yang baik dari nata adalah enak dengan ditambahkan larutan gula 10\%, sehingga dapat berasa manis dan enak. 
Tabel 6. Skor Rasa akibat Pemberian Sari Ubi Jalar Ungu

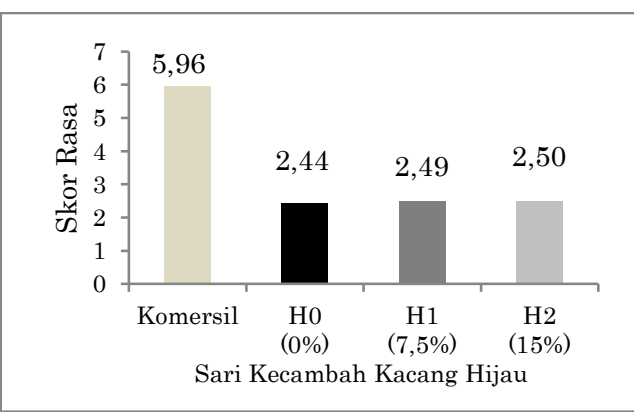

Gambar 6. Skor Rasa akibat Pemberian Sari Kecambah Kacang Hijau

\begin{tabular}{cc}
\hline Perlakuan & Rasa \\
\hline J0 (Sari Ubi Jalar Ungu 0\%) & $2,66^{\mathrm{b}}$ \\
J1 (Sari Ubi Jalar Ungu 15\%) & $2,19^{\mathrm{a}}$ \\
J2 (Sari Ubi Jalar Ungu 30\%) & $2,59^{\mathrm{b}}$ \\
\hline Komersil & 5,96 \\
\hline
\end{tabular}

Skor: (1) Sangat tidak enak, (2) Tidak enak, (3) Kurang enak, (4) Netral, (5) Agak enak, (6) Enak, (7) Sangat enak.

Nilai tertinggi dari skor rasa (Tabel 6) pada Nata de Coco ialah 2,66 dengan perlakuan J0 (sari ubi jalar ungu 0\%), dan jika dilihat dari semua perlakuan memiliki nilai berkisar 2 yang berarti tidak enak. Hal ini disebabkan oleh pengujian organoleptik rasa yang tidak diberikan larutan gula sehingga panelis tidak menyukai rasa dari Nata de Coco yang hambar.

\section{Uji Organoleptik Tekstur}

Berdasarkan hasil analisis ragam sari kecambah kacang hijau dan sari ubi jalar ungu terhapat organoleptik tekstur terjadi interaksi. Tetapi, penambahan sari kecambah kacang hijau tidak berpengaruh nyata dan penambahan sari ubi jalar ungu berpengaruh nyata terhadap organoleptik tekstur.

Tabel 7. Skor Tekstur akibat Pemberian Sari Kecambah Kacang Hijau dan Sari Ubi Jalar Ungu

\begin{tabular}{|c|c|c|}
\hline \multicolumn{2}{|c|}{ Perlakuan } & \multirow[t]{2}{*}{ Tekstur } \\
\hline Sari Kecambah Kacang Hijau & Sari Ubi Jalar Ungu & \\
\hline \multirow[t]{3}{*}{ (H0) $0 \%$} & $(\mathrm{~J} 0) 0 \%$ & $3,11^{\mathrm{a}}$ \\
\hline & (J1) $15 \%$ & $4,51^{\mathrm{c}}$ \\
\hline & (J2) $30 \%$ & $4,00^{\mathrm{bc}}$ \\
\hline \multirow[t]{3}{*}{ (H1) $7,5 \%$} & (J0) $0 \%$ & $4,24^{\mathrm{c}}$ \\
\hline & (J1) $15 \%$ & $3,36^{\mathrm{ab}}$ \\
\hline & (J2) $30 \%$ & $4,49^{\mathrm{c}}$ \\
\hline \multirow[t]{3}{*}{ (H2) $15 \%$} & (J0) $0 \%$ & $3,51^{\mathrm{ab}}$ \\
\hline & (J1) $15 \%$ & $4,03^{\mathrm{bc}}$ \\
\hline & (J2) $30 \%$ & $3,95^{\mathrm{bc}}$ \\
\hline Komersil & & 5,36 \\
\hline
\end{tabular}


Nilai tertinggi terdapat pada perlakuan penambahan sari kecambah kacang hijau 0\% dan perlakuan penambahan sari ubi jalar ungu 15\% yang menunjukkan nilai sebesar 4,51 yang menunjukkan nilai berupa netral. Panelis memberikan nilai berkisar 3 dan 4 yakni kurang enak sampai netral. Hal ini dapat disebabkan karena tekstur yang dihasilkan oleh produk nata yang dibuat rataratanya memiliki tekstur yang cenderung agak alot dan susah dikunyah. Nilai tekstur bisa lebih enak untuk dikunyah dan tidak a lot karena dilakuakn perebusan dengan air gula yang data membuat jalinan selulosa menjadi lebih longgar sehingga tekstur mudah untuk dikunyah (Widia 1984 dalam Putranto, 2017).

\section{Uji Organoleptik Warna}

Berdasarkan hasil analisis ragam sari kecambah kacang hijau dan sari ubi jalar ungu tidak terjadi interaksi. Penambahan sari kecambah kacang hijau tidak berpengaruh nyata terhadap organoleptik warna, sari ubi jalar ungu berpengaruh nyata terhadap organoleptik warna. Nilai skor tertinggi pada organoleptik warna (Gambar 7) ialah H1 (sari kecambah kacang hijau 7,5\%). Pada pengujian organoleptik warna ini, panelis masih membandingkan warna dari nata hasil penelitian dengan yang sudah biasa beredar umum. Sehingga panelis masih memakai produk umum yang berwarna putih bening ini sebagai patokan dari tingkat menariknya produk nata olahan. Putranto, dkk. (2017) yang menyatakan bahwa warna nata yang diberikan ekstrak tauge pada media fermentasinya akan menghasilkan warna putih krem.

Tabel 8. Skor Warna akibat Pemberian

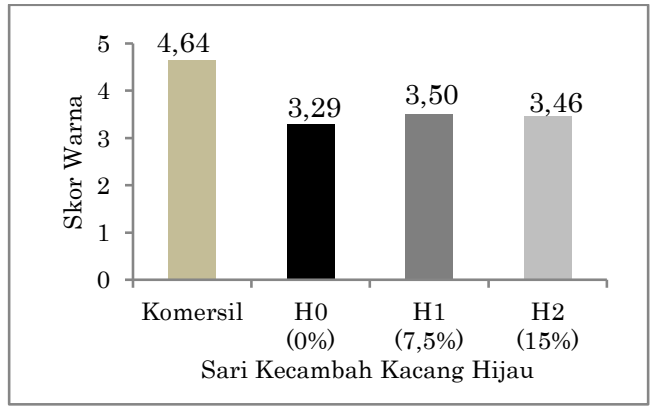

Gambar 7. Skor Warna akibat

Pemberian Sari Kecambah Kacang Hijau Sari Ubi Jalar Ungu

\begin{tabular}{lc}
\multicolumn{2}{c}{ Sari Ubi Jalar Ungu } \\
\hline Sari Ubi Jalar Ungu & Warna \\
\hline J0 (Sari Ubi Jalar Ungu 0\%) & $4,73^{\mathrm{b}}$ \\
J1 (Sari Ubi Jalar Ungu 15\%) & $2,64^{\mathrm{a}}$ \\
J2 (Sari Ubi Jalar Ungu 30\%) & $2,88^{\mathrm{a}}$ \\
\hline Komersil & 4,64 \\
\hline
\end{tabular}

Skor: (1) Sangat tidak enak, (2) Tidak enak, (3) Kurang enak, (4) Netral, (5) Agak enak, (6) Enak, (7) Sangat enak.

Hasil penelitian ini produk nata yang diberi perlakuan pemberian sari ubi jalar ungu (Tabel 8) dengan konsentrasi 15\% dan 30\% akan memiliki warna ungu. Warna ungu tersebut didapat karena pada ubi jalar ungu memiliki pigmen ungu 
antosianin yang menyebar dari kulit sampai daging umbinya (Pokorny dkk., 2001 dalam Fendri, dkk., 2018). Warna ungu akan semakin pekat dengan seiring meningkatnya konsentrasi dari penambahan sari ubi jalar ungu pada media fermentasi. Ina, dkk (2019) yang menyatakan bahwa semakin tinggi penambahan ubi jalar ungu pada soft candy akan memberikan warna yang lebih pekat.

\section{Total Antosianin Hasil Uji Terbaik}

Pengujian total antosianin dilakukan pada 2 perlakuan terbaik. Perlakuan terbaik diperoleh dari hasil analisis de Garmo. Hasil uji de Garmo menunjukkan bahwa perlakuan H1J2 dan H2J1 adalah perlakuan terbaik ke 1 dan 2.

Tabel 9. Hasil Uji Total Antosianin

\begin{tabular}{llc}
\hline & Perlakuan & $\begin{array}{c}\text { Total Antosianin } \\
(\mathrm{mg} / \mathrm{L})\end{array}$ \\
\hline H0J0 & (Sari Kecambah Kacang Hijau 0\% dan Sari Ubi Jalar Ungu 0\%) & $-0,083$ \\
H1J2 & (Sari Kecambah Kacang Hijau 7,5\% dan Sari Ubi Jalar Ungu 30\%) & 1,335 \\
H2J1 & (Sari Kecambah Kacang Hijau 15\% dan Sari Ubi Jalar Ungu 15\%) & 0,250 \\
\hline Komersil & & 0,000 \\
\hline
\end{tabular}

Hasil analisis total antosianin (Tabel 11) perlakuan H1J2 (Sari Kecambah Kacang Hijau 7,5\% dan Sari Ubi Jalar Ungu 30\%) dengan hasil total antosianin adalah $1,335 \mathrm{mg} / \mathrm{L}$. Terjadi penurunan dari hasil perlakuan terbaik ke satu dan yang ke dua. Penurunan ini dapat dipengaruhi oleh peningkatan sari kecambah kacang hijau yang ditambahkan. Selain itu, antosianin merupakan pigmen larut air sehingga penurunan dapat disebabkan oleh larutnya antosianin yang ada pada Nata de Coco berpindah ke larutan selama masa perendaman dan penyimpanan seperti hasil penelitian Husna, dkk., (2013).

\section{KESIMPULAN}

Terdapat interaksi sari kecambah kacang hijau dan sari ubi jalar ungu terhadap organoleptik tekstur. Pemberian sari kecambah kacang hijau memberikan pengaruh nyata pada ketebalan, serat, organoleptik rasa, dan tekstur pada Nata de Coco. Pemberian sari ubi jalar ungu memberikan pengaruh nyata terhadap ketebalan, organoleptik (tekstur dan rasa), dan memberikan pengaruh sangat nyata terhadap parameter organoleptik warna, tingkat kemerahan (a+), tingkat kecerahan (L), dan kadar serat pada produk Nata de Coco. Perlakuan terbaik menghasilkan Nata de Coco pada sampel H1J2 (Sari Kecambah Kacang Hijau 7,5\% dan Sari Ubi Jalar Ungu 30\%).

\section{DAFTAR PUSTAKA}

Agung. 2012. Ekstraki Antosianin dari Limbah Kulit Ubi Jalar Ungu (Ipomea batatas) Metode Microwave Assisted Extraction (Kajian waktu Ekstraksi 
dan Rasio Bahan; Pelarut). Skripsi. Malang Jurusan THP FTR-Universitas Brawijaya.

Arifiani, N., Sani, T. A., \& Utami, A.S. 2015. Peningkatan Kualitas Nata De Cane Dari Limbah Nira Tebu Metode Bud Chips dengan Penambahan Ekstrak Tauge sebagai Sumber Nitrogen. J. Bioteknologi, 12(2), pp. 29-33. DOI:10.13057/biotek/c120201.

Badan Pengawas Obat dan Makanan Republik Indonesia (BPOM RI). 2011. Peraturan Kepala Badan Pengawas Obat dan Makanan Republik Indonesia Nomor HK.03.1.23.11.11.09909 Tahun 2011 Tentang Pengawasan Klaim Dalam Label dan Iklan Pangan Olahan. Jakarta: Badan Pengawas Obat dan Makanan Republik Indonesia. Hal. 18.

Badan Standarisasi Nasional. 1996. SNI No 01-4317-1996. Nata Dalam Kemasan. BSN. Jakarta.

Fendri, S. T. J., Martinus, B. A., dan Haryanti, \& M. D. 2018. Pengaruh pH dan Suhu Terhadap Stabilitas Antosianin Dari Ekstrak Kulit Ubi Jalar Ungu (Ipomea batatas L. Lam.). Chempublish Journal, 2(2).

Hassan, Z. H. 2014. Aneka Tepung Berbasis Bahan Baku Lokal Sebagai Sumber Pangan Fungsional Dalam Upaya Meningkatkan Nilai Tambah Produk Pangan Lokal. J. Pangan, 23(1). DOI: 10.33964/jp.v23i1.54

Husna, N. E., M. Novita, \& S. Rohaya. 2013. Kandungan Antosianin dan Aktivitas Antioksidan Ubi Jalar Ungu Segar dan Produk Olahannya. J. AGRITECH, 33(3). DOI: 10.22146/agritech.9551

Ikawati, Z. 2014. Heboh Pembuatan Nata de Coco dengan Pupuk ZA, What's the Truht?. $\quad$ Diakses $\quad 18 \quad$ April 2021. https://zulliesikawati.wordpress.com/2015/04/02/heboh-pembuatan-nata-de-cocodengan-pupuk-za-whats-the-truth/

Ina, P. T., A. K. D. Puspawati, G. A. Ekawati, \& G. P. G. Putra. 2019. Pemanfaatan Ekstrak Ubi Ungu sebagai Pewarna Merah pada Soft Candy dan Stabilitasnya. Universitas Udayana. J. Agritech, 39(1), pp.20-29. DOI: 10.22146/agritech.32195

Indrawati., Hanafi., Amalia. I., dan Quentena, N. 2017. Pemanfaatan Limbah Air Kelapa (Pengganti Za) Untuk Pembuatan Nata de Coco. Prosiding Seminar Nasional Politeknik Negeri Lhokseumawe, 1(1), pp. 325-329.

Ji, H., H. X. Zhang, H. T. Li, \& Y. C. Li. 2015. Analysis on the Nutrition Composition and Antioxidant Activity of Different Types of Sweet Potato Cultivars. Journal Food and Nutrition Sciences, 6, pp.161-167. DOI: 10.4236/fns.2015.61017

Laksmiani. N. P. L., Leliqia. N. P. E., Wiriyanti. N. Y. T., Dewi. I. A. P. C., \& Wirasuta. I. M. A. G. 2015. Identifikasi dan Karakterisasi Antosianin Ekstrak Etanol Dalam Suasana Asam Dari Ubi Jalar Ungu (Ipomoea batatas L.) Dengan KLT-Spektrodensitometri. Fakultas MIPA. Universitas 
Udayana. Prosiding. Seminar Nasional Sains dan Teknologi. Universitas Udayana. Kuta

Mahmudatussa'adah, A., Fardiaz, D., Andarwulan, N. \& Kusnandar, F. 2014. Karakteristik Warna dan Aktivitas Antioksidan Antosianin Ubi Jalar Ungu. Jurnal Teknologi dan Industri Pangan, 25(2), pp.176-184. DOI: 10.6066/jtip.2014.25.2.176

Margi, H., Andriyani, M., Wiedyastanto, A., Savitskaya, D., \& Margono. 2017. Pemanfaatan Ekstrak Kecambah Kacang Hijau sebagai Sumber Nitrogen Alternatif dalam Pembuatan Nata De Lerry. Prosiding SNST ke-8 Tahun 2017, 1(1). Universitas Wahid Hasyim Semarang. Semarang.

Martianingsih, N., Sudrajat, H. W., \& Darlian, L. 2016. Analisis Kandungan Protein Kecambah Kacang Hijau (Phaseolus radiatus L.) Terhadap Variasi Waktu Perkecambahan. J. AMPIBI, 1(2), pp.38-42. DOI: 10.36709/ampibi.v1i2.5036

Melina M. 2016. Pengaruh Penggunaan Jus Kecambah Kacang Hijau sebagai Sumber Nitrogen Alternative terhadap Karakteristik Nata De Besusu. Skripsi. Universitas Sanata Dharma, Yogyakarta.

Minerva, E. M. 2013. Pengaruh Perbedaan Campuran Tepung Suweg dan Tepung Daun Kelor Terhadap Daya Serap Air Tepung, Daya Kembang, dan Daya Terima Kerupuk. Diploma Thesis. Universitas Muhammadiyah Surakarta.

Nazhipah, F., Almasyhuri., \& Miranti, M. 2018. Formulasi Nata De Peel Batatas Kulit Ubi Jalar Ungu (Ipomea batatas) dengan Penambahan Asam Cuka Dan Belimbing Wuluh. Jurnal Online Mahasiswa, 1(1)

Ningsih, L., Zakiah, Z., \& Rahmawati. 2021. Fermentasi Nira Kelapa Cocos nucirea L. Dengan Penambahan Ekstrak Kecambah Kacang Hijau Phaseolus radiate L. Pada Pembuatan Nata De Nira. Jurnal Biologi Makassar, 6(1), pp. 57-65

Pratiwi, H., Handoko, P., \& Santoso, A. M. 2012. Optimasi Volume Acetobacter xylinum terhadap Produkvitas Nata de Coco pada Media Minimum. Prosiding. Seminar Nasional Biologi. FKIP UNS. Solo

Putranto, K., A. Taofik. 2017. Penambahan Ekstrak Tauge pada Media Nata de Coco. Jurnal ISTEK, 10(2)

Putri, N. K. M., Gunawan, I. W., \& Suarsa, I. W. 2015. Aktivitas Antioksidan Antosianin Dalam Ekstrak Etanol Kulit Buah Naga Super Merah (Hylocereus costaricensis) Dan Analisis Kadar Totalnya. Jurnal Kimia, 9(2), pp.243-251

Putri, S. N. Y., Syaharani, W. F., Utami, C. V. B., Safitri, D. R., Arum, Z. N., Prihastari, Z. S., \& Sari, A. R. 2021. Pengaruh Mikroorganisme, Bahan Baku, dan Waktu Inkubasi Pada Karakter Nata: Review. Jurnal THP, 14(1), pp.62-74. DOI: 10.20961/jthp.v14i1.47654 
Putriana, I., \& S. Aminah. 2013. Mutu Fisik, Kadar Serat dan Sifat Organoleptik Nata de Cassava berdasarkan Lama Fermentasi. Jurnal Pangan dan Gizi, 04(07). DOI: 10.26714/jpg.4.1.2013.\%25p.

Rosel, D., P. Ardiningsih, \& N. Idawati. 2018. Karakteristik Nata De Jackfruit (Artocarpus heterophyllus) dengan Variasi Konsentrasi Starter Acetobacter xylinum. Jurnal Kimia Khatulistiwa, 7(4), pp. 1-7

Saati, E. A., Theovilla, RRD., Wijanarko, S. B., dan Aulann'iam, SBW. 2012. Optimalisasi Fungsi Pigmen Bunga Mawar Sortiran sebagai Zat Pewarna Alami dan Bioaktif Pada Produk Industri. Jurnal Teknik Industri, 12(2), pp.133-140. DOI: 10.22219/JTIUMM.Vol12.No2.133-140

Safitri, M. P., Caronge, M. W., \& Kadirman. 2017. Pengaruh Pemberian Sumber Nitrogen Dan Bibit Bakteri Acetobacter xylinum Terhadap Kualitas Hasil Nata de Tala. Jurnal Pend. Tek. Pertanian, 3, pp.95-106.

Salim, M., Dharma, A., Mardiah, E., \& Oktoriza, G. 2017. Pengaruh Kandungan Antosianin dan Antioksidan Pada Proses Pengolahan Ubi Jalar Ungu. Jurnal Zarah, 5(2), pp.7-12

Sari, M. T. I. P., Periadnadi, Nurmiati. 2014. Pengaruh Penambahan Ekstrak Daun dan Bubuk Teh, Kopi, dan Coklat Terhadap Fermentasi Nata De Coco. J. Bio. UA, 3(3), pp. 202-206

Septiana, A. T., \& Asnani, A. 2013. Aktivitas Antioksidan Ekstrak Rumput Laut Sargassum duplicatum. Jurnal Teknologi Pertanian, 14(2), pp.79-86.

Sunartono. Pabrik Nata de Coco Berbahan Pupuk ZA Digrebek. [diakses tanggal 1 November 2015]. m.harianjogja.com/baca/2015/04/01/pabrik-nata-de-cocoberbahan-ccpupuk-za-digrebek-590429.

Suryono. C., Ningrum, L., \& Dewi, T. R. 2018. Uji Kesukaan dan Organoleptik Terhadap 5 Kemasan dan Produk Kepulauan Seribu Secara Deskriptif. Jurnal Pariwisata, 5(2). DOI: 10.31294/par.v5i2.3526

[USDA] United State Departement of Agriculture. 2018. USDA National Nutrient Database for Standart Reference. www.nal.usda.gov/fnic/foodcomp/search/ (diakses 28 Januari 2021).

Wulaisfan, R., N. Adi, \& M. Nurhidayat. 2016. Aktivitas Antioksidan Ekstrak Etanol Kecambah Kacang Hijau (Phaseolus radiatus L.) Menggunakan Pereaksi DPPH Secara Spektrofotometri UV-Vis. Warta Farmasi, 5(1), pp.66-71. DOI: 10.46356/wfarmasi.v5i2.41. 